Andrzej Melezini

\title{
INFLUENCE OF THE EUROPEAN COURT OF JUSTICE JURISPRUDENCE ON THE APPLICATION OF TAX LAW IN POLAND
}

I The European Court of Justice (hereinafter the ECJ), its full name being the Court of Justice of the European Communities, according to Article 7 of the Treaty establishing the European Community ${ }^{1}$ (hereinafter the TEC) is one of the institutions of the European Communities (hereinafter the EC). As the chief judicial body of the EC, according to the Article 220 of the TEC, the ECJ ensures the observation of the law in the interpretation and application of the TEC. Its jurisdiction embraces legality control of the Community acts (recours de la légalité), actions on responsibility (recours de pleine juridiction) and preliminary rulings (renvois préjudiciels). The aim of ECJ's activity is to control and ensure the observation of the EC internal legal order, while on the grounds of tax law, the ECJ is to protect the taxable person against the lack of neutrality, certainty and stability of taxation. The ECJ's role is also to ensure uniform application of Community legislation, which is performed by giving preliminary rulings (Article 234 of the TEC), which directly bind the national courts. In the period 2001-2007, of the total number of 2891 direct actions, 246 of them, i.e. $8.5 \%$, concerned taxation matters. In 2007 alone, of the total number of 222 direct actions submitted to the ECJ, 48 of them concerned taxation matters (42 references for a preliminary ruling, 6 direct actions) ${ }^{2}$. There is no doubt that the rich jurisprudence of the ECJ serves the Member States as a signpost for changes in their internal legislation to match the EC pattern.

II The basic EU legal principle, i.e. the principle of supremacy of the EU law to national laws, came into force in Poland with Poland's accession to the European Union (hereinafter the EU) on May $1^{\text {st }}, 2004^{3}$. All doubts which arose over the application of the EU law primacy principle on the grounds of Polish tax law, were dismissed by the ECJ judgement in the case Erich Ciola v Land Vorarlberg ${ }^{4}$. In that 
judgement, the Court rules, that all administrative bodies of each Member State are subject to the obligation as to primacy of Community law. The administrative court (in Poland: the Voivodship Administrative Court - as the court of first instance, and the Supreme Administrative Court - as the court of second instance) should reverse any administrative decision which is in conflict with Community law. Thus, no specific individual administrative decision that has become final and is in contradiction to Community law should be subject to enforcement. The aforementioned judgement includes another ruling of particular importance, i.e. the principle of supremacy of Community law is applicable not only to national laws laid down after the date of Poland's accession to the EU, but also to all legal acts which came into force before the date of accession. The thesis of the abovementioned judgement was presented by the ECJ as a preliminary ruling referring to the following question: "Does Community law, in particular the provisions on the freedom to provide services in conjunction with Article 10 of the TEC and Article 2 of the Act on the conditions of accession of the Republic of Austria, the Republic of Finland and the Kingdom of Sweden and the adjustments to the Treaties on which the European Union is founded, give the service provider, who is a resident in Austria, the right to assert that the prohibition issued by a specific individual administrative decision adopted in 1990 should not be applied in decisions of the Austrian courts and administrative authorities adopted after the date of accession".

The provisions of Polish national law should be consistent not only with the statutory law of the EC, but also with the EC common law and the ECJ case-law. One of the main principles governing the EU legal order is the procedural autonomy of the EC Member States 5 , according to which the organisation of the judiciary is an exclusive competence of the Member States, and the provisions of Community law may not interfere with national systems of legal protection bodies ("it is for the domestic legal system of each Member State to designate the courts having jurisdiction and to determine the procedural conditions governing actions at law intended to ensure the protection of the rights which citizens have from the direct effect of Community law"). However, the separate and autonomous legal system of each EC Member State should be consistent not only with the constitution of that country, but also with Community law. In this case, the ECJ case-law acts as a link between national laws of the Member States and the model, primary Community law.

On the grounds of Article 10 of the TEC, and the ECJ judgement in von Colson $^{6}$ case, in the case of any inconsistency between the provisions of national

5 ECJ Judgement of December $16^{\text {th }}, 1976$ in case Rewe-Zentralfinanz eG et Rewe-Zentral AG v Landwirtschaftskammer für das Saarland, 33/76, ECR 1976, page 1989

6 ECJ Judgement in case Sabine von Colson and Elisabeth Kamann v Land Nordrhein-Westfalen, 14/83, ECR 1984, page 1891. 
and Community laws, it ought to be eliminated through systemic interpretation of particular national law. Due application of national law with regard to Community law depends chiefly on the administrative courts and tax administration of each Member State, which should safeguard the observation of the rights and obligations under Community law. There is no doubt that the accession to such a macro-structure as the EU is, sooner or later means a need to reform and harmonise any country's domestic legislation with EU law in order to facilitate the application of tax law and prevent the Member States from being held responsible for failure to comply with the provisions of EU law. Unification of tax law among the EU Member States directly influences the strengthening of economic relations among them, which, in turn, translates into free movement of capital, intensified transborder activity of entrepreneurs, and overall improvement of economic conditions of the regions which are lagging behind.

III The adjustment process of Polish tax legislation to meet EU standards began at the point of our country's association with the $\mathrm{EU}^{7}$ and has been continuing since. In order to ensure compliance of the provisions of Polish tax law with EU law, the first stage of harmonisation process regarded the amendment of customs law, banking law, accounting law, direct and indirect taxes. At the moment Poland entered the EU structure, the few still non-unified areas of tax law were covered by interim periods. The unification procedure results from Poland's membership in the EU and the obligations it involves.

The most advanced legislative changes, intended to introduce the provisions of Community directives and ECJ case-law, regarded the Polish Goods and Services Tax Act. Before Poland's accession to the EU, the Constitution of the Republic of Poland was the only legal act of supreme legal power to which taxpayers could refer. The opportunity to submit disputes arising from failed implementation of EU law to the European Court of Justice, forced a thorough reconstruction of the value added tax system. The new VAT Act included not only a modified subjective and objective scope of taxation, but also commencement date of tax obligation and the scope of tax exemptions.

Since Poland's accession to the EU, it has been more and more common and frequent for the Polish administrative courts to refer to the ECJ jurisprudence. The ECJ case-law sets legal precedents, thus indicating the direction of Community law interpretation. In consequence of the application of a specific ECJ ruling, after the tax proceedings have been completed and the administrative decision has come into force, it often turns out that the provisions of material tax law applied to date are contradictory to the EU legal order and should be amended. At such point, the ECJ role is of crucial importance, as it has all the powers to ensure a coherent and 
uniform development of Community law through the internal legislations of the Member States.

IV Judicial control over the legality of tax administration actions is of utmost importance for the correct functioning of tax $\operatorname{law}^{8}$. Whereas, the tax administration itself should competently function in a multicentric law system ${ }^{9}$, which, in place of a classic legal order based on the hierarchy of the sources of law, features two (or more) sub-systems deriving from different centres (Polish and EU). The legal interpretation applied by the ECJ directly influences the application of law and changes in law that is clearly visible in the following examples. The first one refers to the additional tax liability which is stipulated in the Polish tax law at $30 \%$ rate of: understated output VAT, overstated VAT refund or the overstated amount of the tax difference, i.e. the so-called VAT sanction ${ }^{10}$. Such a provision was intended by the legislator to motivate taxpayers to fulfil their tax obligations in a diligent and honest manner. It should be noted at the beginning, that on the grounds of the EU VAT Directives ${ }^{11}$, there are no regulations concerning additional tax liability. As a new EU Member State, Poland enjoyed some derogations in tax law, which offered an opportunity to withdraw from the application of EU legal provisions in a specific period of time, as it was e.g. with the reduction of VAT rate for new housing until the end of 2007. However, the derogation provisions included no regulations regarding the VAT sanction. The Ombudsman approached the Constitutional Tribunal, which is empowered to adjudicate on the conformity of legal provisions to the Constitution, to rule on the non-conformity to the Constitution of the provisions regarding VAT sanction, as they were, in fact, of penal character. The Constitutional Tribunal ruled $^{12}$, that the abovementioned provisions did not conform to Article 2 of the Constitution $^{13}$ in the part, in which the referred provisions allow the application to the same person and same deed of both the administration sanction (described by the Act in question as "additional tax liability") and the "penalty for tax offences" (stipulated in the Penal Tax Code ${ }^{14}$ - hereinafter the PTC). It should be stressed that inaccurate VAT return forms were also penalised under the abovementioned PTC. The Constitutional Tribunal ruled, that imposing double penalty on a natural person for the same deed did not conform to the Constitution, however, according to the

8 R. Mastalski, The Way Judicial Interpretation of Tax Law Changes after Poland's Accession to the EU, "Prawo i podatki" ("Law and Taxes"), No 9/2006, p. 29.

9 R. Mastalski, "The Application of Tax Law", Warsaw, 2008, p. 59.

10 Article 109 of the Goods and Services Tax Act of March 11, 2004 (OJ No 54 pos. 535 with amendments, hereinafter referred to as VAT Act), transferred from the preceding Act of January 8, 1993 on Goods and Services Tax and Excise Tax (OJ No 11 item 50 with amendments).

11 Council Directive 2006/112/EC of 28 November 2006 on the common system of value added tax (OJ L No 347 with amendments).

12 Judgement of the Constitutional Tribunal of April 29, 1998, Ref. K 17/97, published in "The Constitutional Tribunal Jurisprudence" 1998, No 3, item 30 - Professional Tax Service.

13 Article 2 of the Constitution of the Republic of Poland: "The Republic of Poland shall be a democratic state governed by the rule of law and implementing the principles of social justice".

14 Penal Tax Code Act of September 10, 1999 (consolidated version OJ of 2007, No 111, item 765) 
Constitutional Tribunal, it was in line with the Constitution to penalise legal persons, i.e. commercial law companies, in such a way.

Article 27 of Sixth VAT Directive ${ }^{15}$ provided for the possibility to introduce special measures by the domestic legislations of the Member States. However, such special measures could be taken only in order to simplify the procedure for charging the tax or to prevent certain types of tax evasion or avoidance. A Member State wishing to introduce such measures should inform the Commission, which, having consulted the other Member States, should adopt a decision on the matter. It is difficult to state, that any of these conditions could be applied to the abovementioned VAT sanction. Since the sanction's character and the scope of its application were the subject of constant disputes in literature, the Voivodship Administrative Court (tax administration bodies have no right to refer to the ECJ) took interest in the matter and referred to the ECJ for a preliminary ruling on the interpretation of EU directives with regard to the provisions of VAT Act providing for the imposition of additional tax liability ${ }^{16}$. However, since the facts pre-dated the accession of Poland to the EU, the ECJ ordered ${ }^{17}$ that it had no jurisdiction to reply to the question due to ratione temporis obstacle. In another attempt to settle the VAT sanction matter, the Supreme Administrative Court, in its order ${ }^{18}$, referred to the ECJ for a preliminary ruling on the following questions: the possibility of imposing by a tax authority an additional tax liability on a VAT taxable person, and whether such an obligation is a "special measure" within the terms of Article 27(1) of the Sixth VAT Directive, and whether the power provided for in Article 33 of the Sixth VAT Directive encompasses the right to introduce the additional tax liability. It should be noticed that until the ECJ has ruled the case, Polish administrative courts are obliged to suspend proceedings in cases regarding decisions which include elements of VAT sanction construction. The abovementioned doubts expressed both by the administrative courts and in the legal doctrine, resulted in a necessity of reference for the ECJ preliminary ruling. It is the ECJ jurisdiction to assess the conformity of the application of Polish legal provisions to the EU law. What is more, the ECJ ruling in the aforementioned case is anticipated not only by the Supreme Administrative Court but also by the legislators, who are ready to amend the VAT Act and thus eliminate the provisions contradictory to EU Directives.

15 Sixth Council Directive of 17 May 1977 on the harmonization of the laws of the Member States relating to turnover taxes - Common system of value added tax: uniform basis of assessment (77/388/EEC)

16 Order of the Voivodship Administrative Court in Łódź of February 15, 2006, Ref. ISA/Łd 1089/05, www.orzeczenia. nsa.gov.pl

17 ECJ Order of March 6, 2007, OJ of 2007, No C 96, p. 22.

18 Supreme Administrative Court Order of July 31, 2007, Ref. I FSK 1062/06, www.orzeczenia.nsa.gov.pl, issued on the grounds of Article $106 \S 2$ and Article 162 of the Act of August 30, 2002 on the Proceedings Before Administrative Courts (OJ of 2002, No 153, item 1270 with amendments) 
The rulings on the right to deduct input VAT are another example of the influence of the ECJ jurisprudence on Polish tax law. The provisions of the Polish VAT Act limit the right to deduct input VAT in several cases ${ }^{19}$ (treating it as a privilege granted to the taxable person), e.g. there is no possibility to deduct input tax if the expenditure on purchase of goods or services could not be classified as tax-deductible costs within the terms of income tax acts ${ }^{20}$, or when the taxable person carries out a legal transaction which lacks the form prescribed by the Civil Code ${ }^{21}$. It should be stressed that one of the fundamental principles of the value added tax is its neutrality. The rule of neutrality constantly strives to seek, implement and protect such legislative solutions, which will ensure that the amount of tax paid by the taxable person in the price of goods and services purchased and used for the purposes of conducting taxable activity will not constitute final cost for the taxable person ${ }^{22}$. In this scope, the ECJ case-law safeguards the observation of the aforementioned principle, stressing that the basic condition of the right to deduct input VAT is the relation between the tax and conducting economic activity, and that the only exception to the right to deduct input VAT is when the taxable person knew or should have known that by purchasing goods s/he was participating in a transaction connected with fraudulent evasion of VAT on the grounds of Community VAT system. Polish tax legislation was not the only one to have been criticised in the abovementioned scope ${ }^{23}$. At this point, the essence of the judgement in joined cases Axel Kittel and Recolta Recycling ${ }^{24}$ is worth mentioning, in which Belgian tax authorities refused the right to deduct the VAT paid in transactions used in so-called carousel tax fraud ${ }^{25}$. The question the ECJ had to address was the following: "If the recipient of supplied goods is a taxable person who has entered into a contract in good faith without knowledge of a fraud committed by the seller, does that taxable person have the right to deduct input VAT?". In its judgement, the ECJ ruled that under civil law provisions taxable person cannot lose the right to deduct the VAT s/he has paid in the case when a taxable person did not know that the transaction was connected with a tax fraud, however, the contract of sale is found null and void. In such a situation, refusal of the right to deduct input

19 Article 88 (3a) of the Goods and Services Tax Act of March 11, 2004 (OJ of 2005, No 54, item 535)

20 There are two acts on income taxes in Poland: Personal Income Tax Act of July 26, 1991 (consolidated version OJ of 2000, No 14, item 176 with amendments), and Corporate Income Tax Act of February 15, 1992 (consolidated version OJ of 2000 , No 54 , item 654).

21 Civil Code Act of April 23, 1964 (OJ of 1964, No 16, item 93 with amendments)

22 K. Sachs Sixth VAT Directive, Warsaw, 2004, p. 417

23 ECJ Judgements: of 21 March 2000 in case C-110/98 Gabalfrisa SL and Others v Agencia Estatal de Administración Tributaria, of 8 January 2002 in case C-409/99 Metropol Treuhand WirtschaftsstreuhandgmbH v Finanzlandesdirektion für Steiermark, J. Martini, Ł. Karpiesiuk VAT in the European Court of Justice Case-Law, Warsaw 2005, p. 390

24 K. Tetłak Gloss on the ECJ Judgement of July 6, 2006 on joined cases Axel Kittel v Belgium and Belgium v Recolta Recycling SPRL, Tax Review 2007, No 2, p. 47

25 A taxable person residing in Member State A sells goods to a taxable person residing in Member State B. Within the discussed taxation mechanism the exported goods are "VAT free" in their country of origin (A). Still, the supplier has the right to deduct input VAT. At the same time, the buyer should charge VAT at the rate prevailing in the country of destination (B). 
VAT would violate an integral part of the Community VAT system. The principle of VAT neutrality precludes a rule of national law which results in the loss of the right to deduct the VAT paid, due to the fact that the contract of sale is incurably void as contrary to public policy. To summarise, one should state, that Polish regulations on VAT deduction do not comply with the principle of neutrality, thus are in contradiction to Community regulations ${ }^{26}$. Until they have been amended, the tax authorities and administrative courts, in this and any other case, should interpret the provisions of national law with regard to EU Directives. Should such a method of interpretation be impossible, national courts, under the principle of supremacy of Community law, are supposed to withdraw from the application of national law provisions. The reference to the ECJ for a preliminary ruling on the abovementioned case, made by national courts would be another option, undoubtedly speeding up the amendment process of these VAT provisions which do not comply with Community law.

The last example I would like to present in this article, to prove the undeniable role the ECJ plays in shaping Polish legal provisions, is the case of excise duty on imported cars. With the accession to the EU, Poland became a part of the Customs Union and, as a result, had to abolish duties on goods imported from other EU Member States. With the view to prevent Polish market from being flooded by second-hand cars, often old and in bad condition (dismantled for parts), The Excise Duty Act introduced the liability to pay excise duty on imported passenger cars older than two years (the older the car, the higher excise rate) and not registered in Poland ${ }^{27}$. Passenger cars imported from other EU countries (classified as nonharmonised goods) are subject to excise duty, the rate of which varies according to the age of the vehicle. In the light of EU law, such a procedure means imposing internal taxation in excess of that which is imposed on similar domestic products on the products of other Member States ${ }^{28}$. This case constitutes a breach of the principle of equal taxation, as second-hand vehicles being sold in Poland are not subject to excise duty. The Voivodship Administrative Court in Warsaw, while conducting proceedings in one of the cases on excise duty ${ }^{29}$ levied on cars imported from other EU Member States, referred to the ECJ for a preliminary ruling on the case. In its judgement $t^{30}$, the ECJ ruled that an excise duty such as that introduced in Poland (which does not affect passenger vehicles due to the fact that they cross the frontier) is not a customs duty on import or a charge having equivalent effect within the 84

27 Excise Duty Act of January 23, 2004 (OJ of 2004, No 29, item 257 with amendments)

28 R. Poździk, P. Sawczuk, Excise Duty on Second-hand Cars, European Court Review, 2005, No. 12, pp. 25-35

29 Judgement of the Voivodship Administrative Court in Warsaw of March 6, 2007, Ref. III SA/Wa 254/07, www. orzeczenia.nsa.gov.pl

30 Judgement of the ECJ of January 18, 2007 in case C 313-05, Brzeziński vs Dyrektor Izby Celnej w Warszawie, http://eur-lex.europa.eu/LexUriServ/LexUriServ.do?uri=CELEX:62005J0313:en:HTML 
meaning of Article 25 of the EC. The ECJ also ruled that Article 90 of the EC is to be interpreted as the meaning that it precludes an excise duty, insofar as the amount of the duty imposed on second-hand vehicles, which are over two years old, acquired in a Member State other than that which introduced such a duty, exceeds the residual amount of the same duty incorporated into the market value of similar vehicles which had been previously registered in the Member State which introduced that duty. The ECJ found the Polish provisions contradictory to Community law since Poland joined the EU until the provisions ceased to be in force - i.e. November 30, 2006, when the defective provisions of the Excise Duty Act were amended ${ }^{31}$. In this particular case, the ECJ authorised the Voivodship Administrative Court in Warsaw to calculate the amount of overpayment, while in other cases it is for the Ministry of Finance of the Republic of Poland to prepare a detailed reimbursement procedure having followed a series of unsuccessful attempts. The Excise Duty Reimbursement Act is most likely to come into force by the end of this year.

V The abovementioned examples only fragmentarily present the key role the ECJ plays in the shaping Polish legislation. It is obvious that the unification process of tax legislations within the entire EU is long and requires constant changes. Each ECJ ruling resulting in the withdrawal of legal provisions, which violate the rights and duties of EU citizens, is another step forward towards the development of common taxation model for all EU Member States. Making best use of the achievements and potential of each Member State, the ECJ serves the organisational purpose well by removing provisions in contradiction to Community law and by showing the directions in which tax legislations should develop. It should also be underlined, that the more accurate the Member States are in adapting their domestic legislations to EU standards, the more effective is their contribution in the process of harmonisation of EU taxation. The CCCTB - Common Consolidated Corporate Tax Base project is an example of cooperation of the Member States, initiated out of necessity to eliminate the phenomena, which influence the competitiveness in the whole EU in a negative way. In conclusion, it is worth stressing that the ECJ jurisprudence on the grounds of tax law chiefly contributes to the development of transborder standards, which should result in Europe's economic unification. 


\section{Streszczenie}

Artykuł został poświęcony roli i oddziaływaniu na polską legislację podatkową Europejskiego Trybunału Sprawiedliwości (ETS). Podstawowa zasada prawa Unii Europejskiej - zasada supremacji prawa UE nad krajowymi porządkami prawnym, zaczęła obowiązywać również Polskę z momentem akcesji do struktur wspólnotowych. Rozpoczęty proces przystosowania polskiego ustawodawstwa podatkowego do standardów UE stale jest kontynuowany. Istotnym elementem w tym procesie jest uwzględnianie orzecznictwa ETS w postępowaniu podatkowym i podczas wydawania decyzji. $Z$ drugiej jednak strony okazuje się, że przepisy materialnego prawa podatkowego często stoją w sprzeczności z porządkiem prawnym UE i wymagają zmiany. W tym zakresie znaczącą rolę odgrywa Trybunał, ponieważ zapewnia on spójne i jednolite stosowanie prawa wspólnotowego w porządkach prawnych państw członkowskich.

Autor przedstawia także przykłady zmian w polskim ustawodawstwie podatkowym, które zostały wprowadzone pod wpływem orzecznictwa ETS. 